\title{
EXHUMATION OF RADIOACTIVE
} SOLID WASTES BURIED FOR FOURTEEN YEARS

\section{J. H. HORTON}
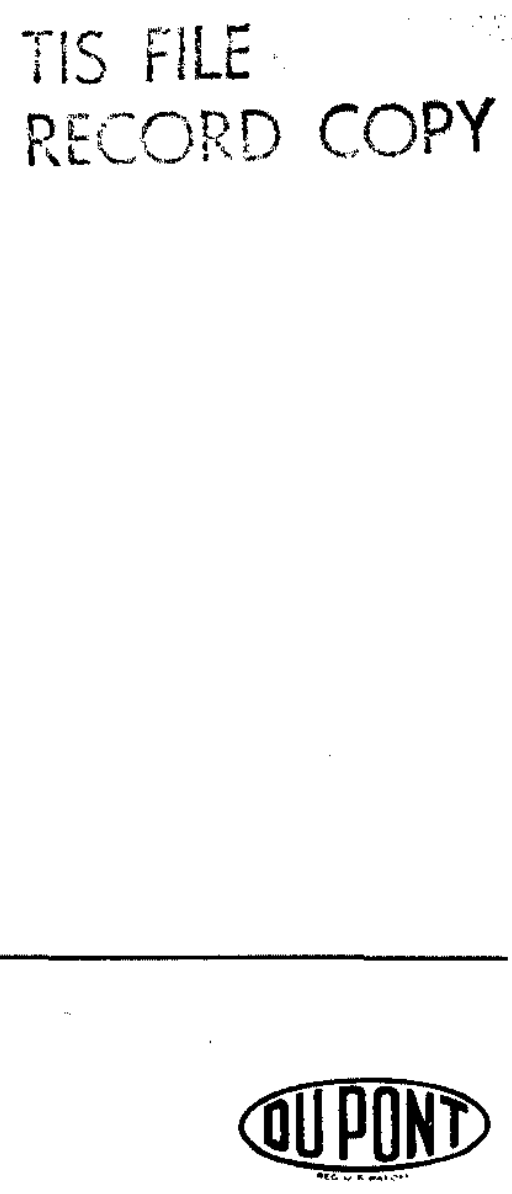

SAVANNAH RIVER LABORATORY

AIKEN, SOUTH CAROLINA 29801

PREPARED FOR THE U.S. ENERGY RESEARCH AND DEVELOPMENT ADMINISTRATION UNDER CONTRACT ATIO7.2) 1 
This report wes prepared as an account of work sponsored by the United Stetes Government. Neither the United States nor the United States Enerav Reweorch and Development Administration, nor any of their contractors, subcontractors, or their employees, makes any warranty, express or implied, or aseumes any legal liability or responsibility for the accuracy, completeness or usefulnass of any information, apparatus. product or process dieclosed, or represents that its use would not infringe privately owned rights.

Printed in the United States of America

Available from

National Technical Information Service

U.S. Department of Commerce

5285 Port Royal Road

Springfield, Viroinia 22161

Price: Printed Copy $\$ 3.50$; Microfiche $\$ 3.00$ 
DP- 1456

Distribution Category: UC-70

\section{EXHUMATION OF RADIOACTIVE SOLID WASTES BURIED FOR FOURTEEN YEARS}

by

J. H. Horton

Approved by

E. L. Albenesius, Research Manager

Environmenta] Effects Division

Publication Date: March 1977

E. I. DU PONT DE NEMOURS AND COMPANY

SAVANNAH RIVER LABORATORY

AIKEN, SOUTH CAROLINA 29801

PREPAREO FOR THE U. S. ENERGY RESEARCH AND DEVELOPMENT ADMINISTRATION UNDER CONTRACT ATI07-2):1 


\section{ABSTRACT}

Twenty-five linear feet of a low-level beta-gamma waste trench was excavated fourteen years after the waste was buried. The waste included wood, steel, plastics, cotton cloth, rubber, and paper. Cardboard boxes not enclosed in plastic were the only materials to deteriorate visibly. Apparently, decades would be required for all cellulose materials to decompose, and plastics and metals would survive indefinitely. 


\section{CONTENTS}

Introduction 7

Site Characteristics 7

Burial Method 7

Excavation Methods and Results 8

Conclusions 9

References 12

\section{LIST OF F IGURES}

1 Excavated Soil and Waste

2 Material Uncovered in the Partially Excavated Waste Trench

3 Darkened Soil Surrounding Buried Waste

4 Cross-Section of Waste and Soil in Partially

Excavated Waste Trench 


\section{EXHUMATION OF RADIOACTIVE SOLID WASTE BURIED FOR FOURTEEN YEARS}

\section{INTRODUCTION}

The deterioration of radioactive solid waste in soil is an important consideration when estimating migration of radionuclides from the burial site, planning procedures for exhuming buried waste, and evaluating hazards caused by intentional or unintentional uncovering of the waste. Very little information has been reported on the exhumation and examination of buried radioactive waste. Steel drums of waste were recovered 12 years after burial in the semi-arid environment of the National Reactor Test Site in Idaho and were generally in poor condition due to corrosion. ${ }^{1,2}$ This report presents observations during the excavation of low-level waste buried for 14 years in the humid environment of the Savannah River Plant.

\section{SITE CHARACTERISTICS}

The site for burial of solid radioactive waste is located in an area of unconsolidated sands, clayey sands, sandy clays, and clays, which extend to a depth of nearly 1000 feet. ${ }^{3}$ The rainfall averages 47 inch/year; but because of surface runoff and evaporation, only about $15 \mathrm{inch} /$ year flows through the soil to the water table. The average depth to the water table is about 45 feet. In the unsaturated zone above the water table, the vertical percolation rate of water is about 7 feet/year. Because water permeability is higher in backfilled than in undisturbed soil, the bottom of some trenches can contain perched water. However, the duration and/or extent of the perched water is limited so that most waste is not subjected to water saturated soil.

\section{BURIAL METHOD}

Burials are made in trenches that are approximately 20 feet deep and 20 feet wide. The waste is segregated into transuranium alpha, low-level, and high-level waste categories. Low-level beta-gamna waste (measures $<50 \mathrm{mR} / \mathrm{hr}$ from an unshielded package or $<50 \mathrm{mR} / \mathrm{hr}$ at 10 feet from a truck load) is unloaded manually or emptied directly into trenches. The waste is covered with a minimum of 4 feet of soil soon after burial to reduce radiation, contamination, and the possibility of fire. 


\section{EXCAVATION METHODS AND RESULTS}

In 1972 , a test excavation was made in a low-1evel betagamma trench that had been filled in 1958. After the test location was selected, a strip of soil 5 feet wide and 30 feet long was excavated perpendicular to the direction of the trench to accurately locate the trench. At a depth of seven feet, three packages or pieces of waste were found several feet apart horizontally and extending across most of the 30-foot width of the trench. Once the location of the trench was defined, the overburden from a $25 \times 30$-foot section of trench was removed to expose the top surface of buried waste. This soil was excavated with a mechanical shovel that removed layers of soil only 1 to 2 inches thick and 5 feet wide and left a very smooth surface.

When the 7 feet of overburden had been removed from the test section of trench, ten pieces or packages of waste had been uncovered, an average of one piece per 75 square feet.

The excavation was continued with a hydraulic clam-shell which removed 6 to 12 inches of soil per scoop from a $2 \times 4$-foot area. With this equipment, an area one-half of the width of the trench and 25 feet long was excavated to the bottom of the trench which was 17 feet below ground surface. The excavation was continued 2 to 3 feet for positive assurance that the bottom had been reached. Until the trench bottom was reached, very few clamshells were filled with soil that did not contain some waste. No water-saturated soil was encountered, and the excavation revealed that the trench was in sandy clay.

The excavated waste included a wooden box, lumber, steel bars, steel pipe, steel rods, electrical cords, rope, tarpaulins, polyethylene bags, both plastic and cotton cloth shoe covers, rubber overshoes, rubber gloves, cardboard boxes, papers, and steel planchets. Some of these are visible in the pile of excavated soil and waste shown in Figure 1. Most of the waste was exceptionally we11 preserved. Some cotton cloth buried without encapsulation in plastic was still strong and could be heard tearing when pulled apart by the clam-shell. Unencapsulated cardboard boxes showed the only visible evidence of decay, but they could be recognized. Cardboard that had been protected inside of plastic bags was in excellent condition as shown in Figure 2. Writing on paper inside the plastic bags was legible, and dirt on a plastic shoe cover due to use also was easily visible (Figure 2). In nearly all cases, soil around the waste was dark colored as if stained 
by decaying organic material, and most of this probably came from cardboard boxas (figure 3). This colox extended several feet below the trench botcom. All of the waste was wet including that in unsealed plastic bags.

Before the test it was thought that the waste and soil would be fairly well separated because data from drill holes and soll cores collected from trenches before the excavation showed layers of waste and layers of soil. The excavation rem vealed that these layers are so distorted that clean soil in the waste zone in the trench would be very difficult to separate in the fideld with mechanical equipment (Figure 4).

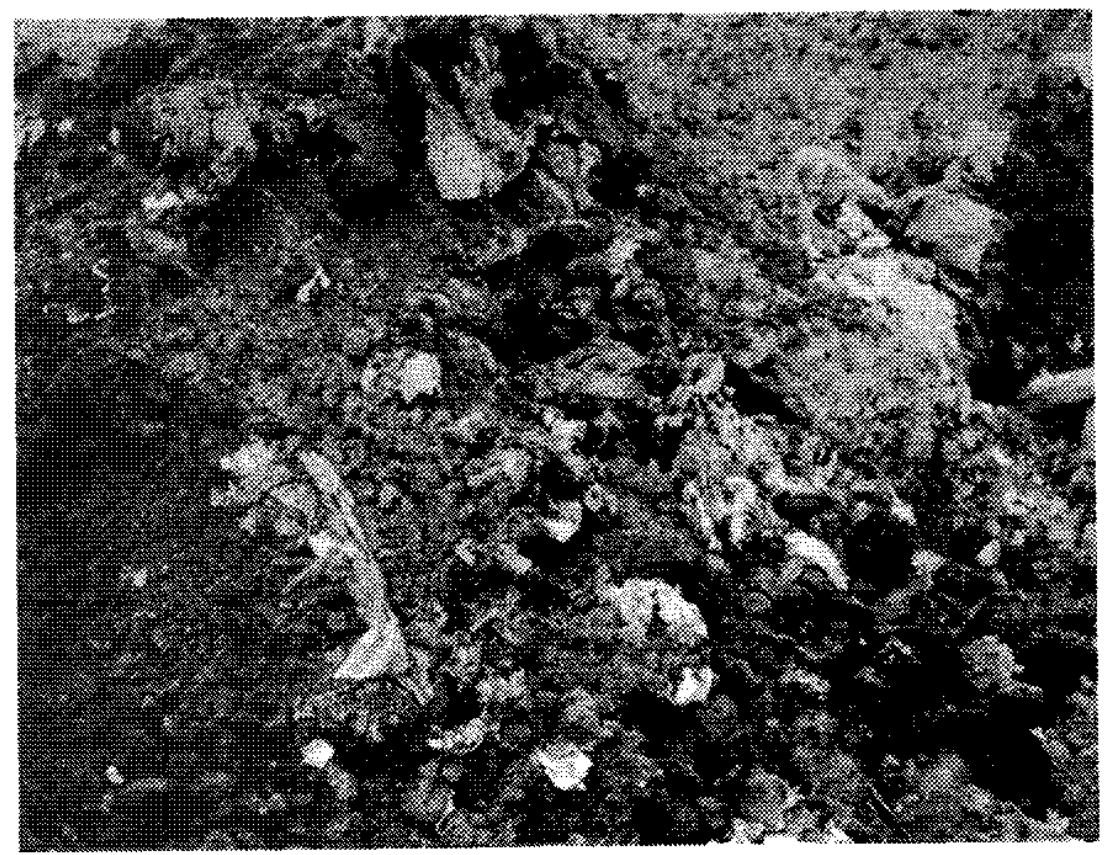

FIGURE 1. Excavated Soll and Waste 

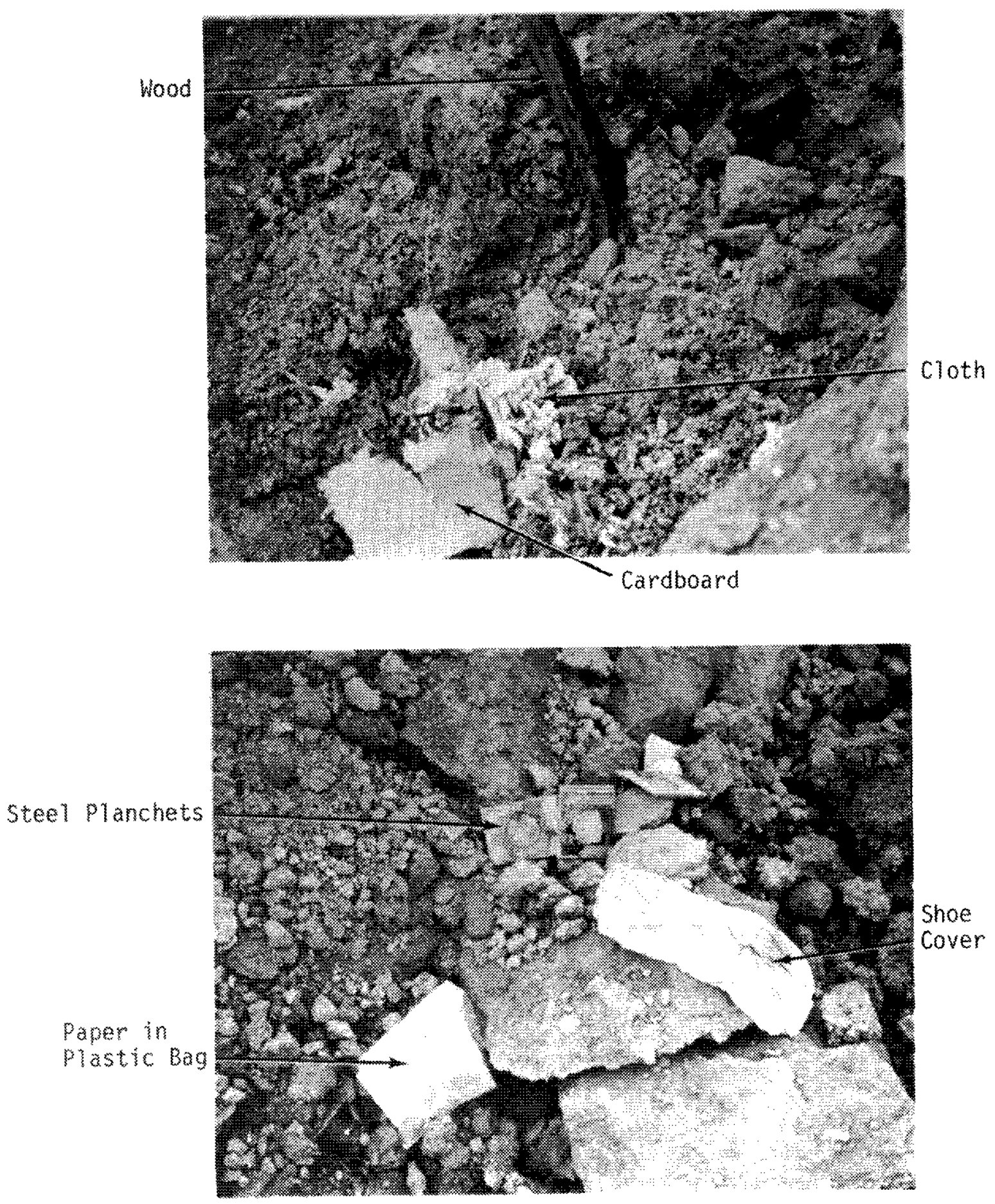

FIGURE 2. Material Uncovered in Partially Excavated Waste Trench 


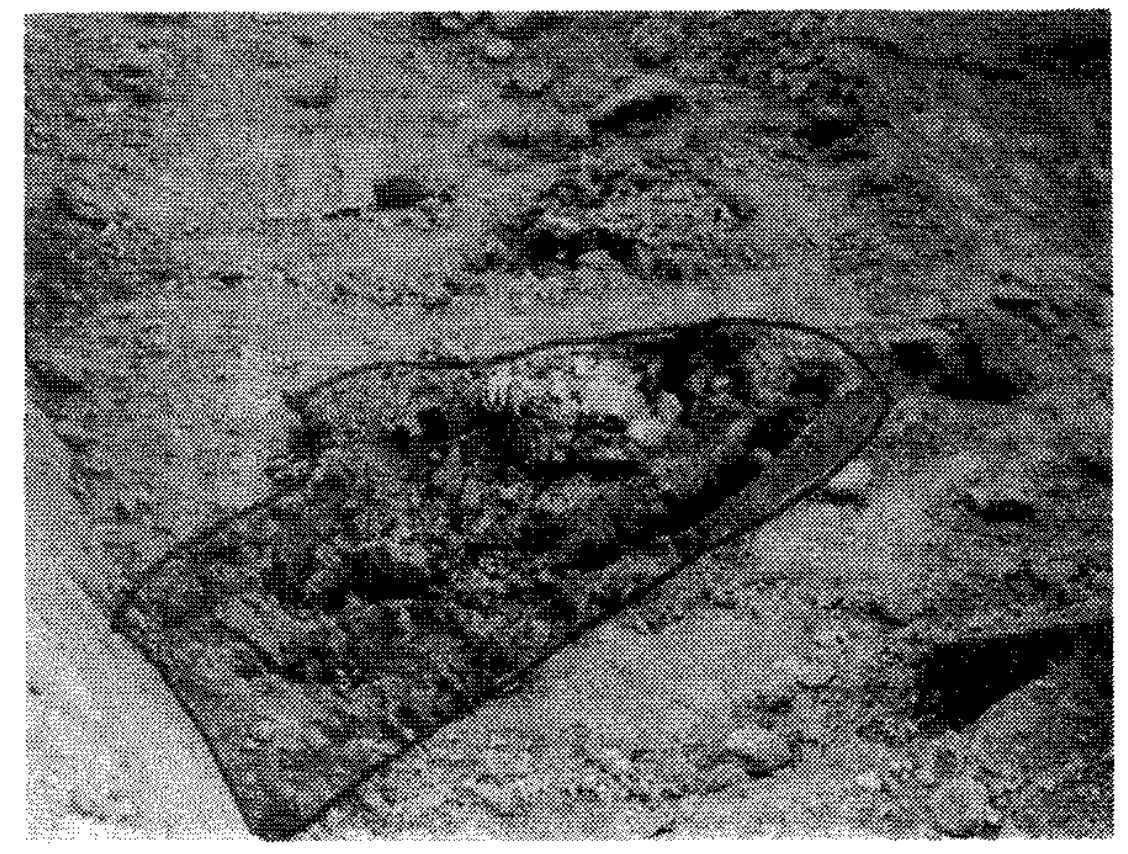

FlauRE 3. Darkened Soil Surrounding Buried Waste

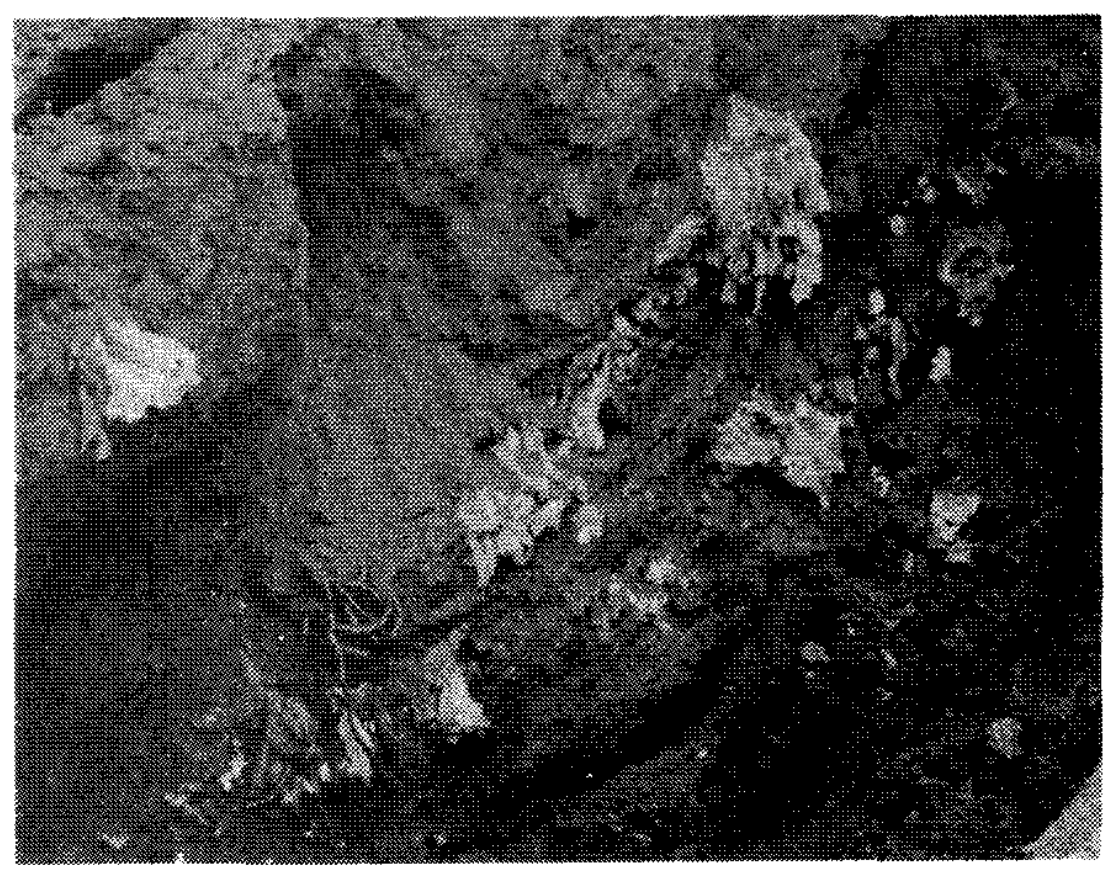

FigURE 4. Cross Section of waste and Soll in Partially Excavated Waste Trench 


\section{CONCLUSIONS}

The observations during this study led to the following conclusions.

1. The decomposition of materials buried in water-unsaturated soil at the Savannah River Plant is very slow. This is not unexpected for plastics and rubber but is surprising for cotton cloth, paper, and wood. The slow decomposition of these materials may be due to a deficiency of oxygen or nitrogen. ${ }^{4}$ Cotton cloth, paper, and wood are decomposed by soil micro-organisms. With a deficiency of oxygen, the decomposition by aerobic organisms is diminished, and both aerobic and anaerobic organisms require an adequate supply of nitrogen for their growth. Savannah River Plant soils are naturally low in nitrogen and so are cotton cloth, paper, and wood.

2. Complete decomposition of wood, cotton cloth, and paper will require several decades.

3. Metals will survive indefinitely.

4. Plastics and materials encapsulated in plastics will survive indefinitely provided radiation from the waste is not sufficient to destroy the plastic.

5. The slow decomposition of waste should inhibit the dispersion of radionuclides in the waste. 


\section{REFERENCES}

1. The Shallow Land Burial of Low-Level Radioactively Contaminated Solid Waste. pp. 26 and 74. Prepared by Panel on Land Buria1, Committee on Radioactive Waste Management, Commission on Natural Resources, National Research Council, National Academy of Sciences, Washington, DC (1976).

2. R. J. Thompson. Solid Radioactive Waste Retrieval Test. USAEC Report ACI-120, Allied Chemical Corporation, Idaho Fal1s, ID (1972).

3. J. H. Horton and J. C. Corey. Storing Solid Radioactive Wastes at the Savannah River RZant. ERDA Report DP-1366, E. I. du Pont de Nemours \& Company, Savannah River Laboratory, Aiken, SC (1976).

4. M. Alexander. Introduction to Soil Microbiology. p. 165, John Wiley, New York (1961). 